\title{
PARASITES OF FRESHWATER AND CONDITION FACTOR OF BAGRID FISHES IN ANAMBRA RIVER BASIN, NIGERIA
}

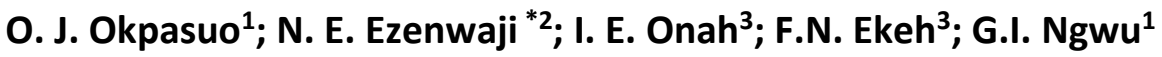 \\ ${ }^{1}$ Department of Zoology and Environmental Biology, Parasitology Unit, Faculty of Biological Sciences, \\ University of Nigeria, P.O.Box 3146, Nsukka, Enugu State,Nigeria . \\ ${ }^{2}$ Department of Zoology and Environmental Biology, Physiology/ Applied Fisheries Unit, University of Nigeria, \\ P.O.Box 3146, Nsukka, Enugu State,Nigeria . \\ ${ }^{3}$ Department of Zoology and Environmental Biology, Entomology Unit, University of Nigeria, P.O.Box 3146, \\ Nsukka, Enugu State,Nigeria .
}

*Corresponding Author Email: ngozi.ezenwaji@unn.edu.ng

\begin{abstract}
Parasitological investigation of bagrid fishes in Anambra River Basin in Anambra state, Nigeria was carried out for two months between the month of April and May, 2015. A total of 102 bagrid fishes belonging to 4 genera and 7 species were subjected to parasitological investigation, only 32 fishes were infected with a parasitic prevalence of 31.4\%. The species included Bagrus bayad, Auchenoglanis monkei, Auchenoglanis occidentalis, Auchenoglanis biscutatus, Bagrus docmac, Chrysichthys auratus and Clarotes laticeps. A higher prevalence (42\%) in all the bagrid species sampled in relation to sex was found in the female while the male had the lesser prevalence (26.2\%). The female had higher mean intensity (4.76) than the male (3.09). The parasites recovered were a monogenean Gyrodactylus; three nematode species Procamallanus laevichonchus, Camallanus and Capillaria; a cestode Wenyonia and an Acanthocephala Polymorphus spp, unidentified leech. Auchenoglanis biscutatus harboured the most amount of parasite while Bagrus docmac harbored the least amount of parasite. The gills, skin, fins, stomach, and intestine were infected with parasite. The findings of this study on Bagrus fishes revealed that the condition factor ranged from $0.75 \pm 0.02-1.61 \pm 0.74$. The finding also shows that the $b$ values of show a sign of negative allometric growths. The $b$ values for the LWR of were under the range from 1.296 in A. Occidentalis to 2.181 in A. Biscutatus.
\end{abstract}

\section{KEY WORDS}

Bagrid fishes, Parasites: Monogenean; nematode; cestode; an Acanthocephala, condition factor, Anambra River Basin.

\section{INTRODUCTION}

Bagrids are freshwater fish of Africa, Southern and Eastern Asia. They are commonly found in major lakes and rivers. Bagrids are also a very diverse family ranging from Bagrus meridionalis, the largest fish native to Lake Malawi, to the diminutive Hyalobagrus flavus of Southeast Asia that rarely exceeds one inch. They are common in commercial catches at the Anambra river basin where they provide rich protein source in the diets of the populace. In Nigeria, fish consumption is increasing especially among the poor majority because of its affordability and health benefits (Ekanem et al., 2011). Knowledge of the biology of Bagrids is important for its management and sustainable utilization of the stock, thus, biological assessment has been carried out by many authors including Ezenwaji (2004) and Ekanem (2002) to determine the quality and populations of the species in different water bodies in Nigeria. Most of the species fed on small fishes, insects, and plant detritus (Baron et al., 1996a). Fishes are a source of vectors for human pathogen. All species of fish are vulnerable to various parasitic infections depending on the species 
and the type of water body inhabited. Some of the factors that enhance parasitic infection in fish include oxygen content of the water, increase of organic content in water and poor environmental conditions. Parasite infections in fish reduces production and economic losses through direct fish mortality, reduction in fish growth, fecundity, and stamina, increase in the susceptibility of fish to diseases, predation, and high cost of treatment. Intensive fish culture favours the spread of many diseases and parasites (Anyanwu, 1991). The parasite checklist of Khalil and Polling (1997), documented a sparse parasite fauna for some species of bagrid fishes recording the occurrence of Protoancylo discoids, chrysichythys, Wenyonia minuta, and Proteocephalus beauchamp in C. nigrodigitatus, Nilonema gymnarchi in the lung-like air bladder sacs of Gymnarchus niloticus and Thwaitia bagri, under the skin lateral to the mouth in Bagrus bayad. Hoffman (1999) recorded infections by camallanids (Paracamallanus cyathopharynx and Procamallanus laevionchus) in Bagrus bayad and Auchenoglanis biscutatus. Fomena et al., (1997) also revealed the presence of Myxosporidea species of the genus Henneguya, such as H. Auchenoglanis in Auchenoglanis occidentalis and H.chrysichthys in Chrysichthys nigrodigitatus affecting the gill and intestine of the fishes. Obiekeizie et al., (1988) reported the occurrence of Aspidojastrid trematodes and Aspidogastrea africanus in C. nigrodigitatus.

Several authors have studied the length-weight relationships of various fish species from different waters. The condition factor according to Le Cren (1951) attempted to solve the deficiencies of Fulton's by comparing the actual weight to a standard weight predicted by the weight-length regression based on the population from which the fish was sampled. Lengthweight relationship studies are important in managing and conserving fish species in one habitat. Meanwhile, the condition factor $(K)$ of fish are considering the general well-being and health of a fish in relation to its environment, thus it represents how robust or deep bodied of the fish are (Reynold, 1968). The Lengthweight Relationship (LWR) studies are important in fisheries biology due to the fact that, they are useful in estimation of the average weight of fish, based on a given length group which come from the mathematical standard set-up between the two (Beyer, 1987). The length-weight relationships provide information on the growth patterns and condition of one fish (Bagenal and Tesch, 1978). Seasonal variations of $\mathrm{K}$ were also observed by previous researchers and according to Gallardo-Cabello et al. (2007) the K of fish diminished when the food availability in one area decreased. LeCren (1951) observed that the analysis of length and weight data had usually been directed towards two rather different objects. The first being towards describing mathematically the relationship between length and weight so that one may be converted into the other, the researcher referred to as length-weight relationship. The second is to measure the variation from the expected weight for length of individual fish or relevant groups of individuals as indications of fatness, general well-being, and gonad development. This is termed condition. Fish are said to exhibit isometric growth when length increases in equal proportions with body weight for constant specific gravity. $\mathrm{K}$ also gives information when comparing two populations living in certain feeding, density, climate, and other conditions; when determining the period of gonad maturation; and when following up the degree of feeding activity of a species to verify whether it is making good use of its feeding sources.

Therefore, this study seeks to investigate the parasitic fauna of Bagrid fishes sampled from Anambra River basin.

\section{MATERIALS AND METHOD}

Fresh Fishes were randomly selected from commercial fishermen around Otuocha, Anam and Nsugbe in the lower reaches of the Anambra river from April and May 2015. The geographical location, climate, vegetation, and other features of this area in the Anambra river basin have been described (Ezenwaji, 1998). A total of 102 randomly selected Bagrid fishes were bought. The samples collected were placed in a large open plastic bucket with water, and transported to the fishery laboratory, University of Nigeria Nsukka. The fish species were identified with standard taxonomic work of Olaosebikan and Raji, (1998); Idodo-Umeh, (2003). Specimen were weighed to the nearest gram, while the standard length (snout to the end of caudal peduncle) (SL, to the nearest centimetre) and their sexes were determined by examination of the gonads by pressing the stomach for melt, egg and during dissection. Examination of Samples for Ecto and Endoparasites: The external and internal organs were thoroughly 
examined for ecto and endoparasites using hand lens while mucous scrapings using scalpel blade were done on the samples skin, fins, and gills independently and placed in different containers containing $3 \mathrm{mls}$ of normal saline solution $(0.9 \%$ solution of $\mathrm{NaCl})$. Scrapings from the fins, skin and gills of the fish samples that were placed in a normal saline were stirred using a mounted pin. Some drops of the mixed solution were collected using dropper, placed on a slide, and then covered with a cover slip after which observation on a light microscope was made for abundance and distribution of ectoparasites. The gills were dissected out and each of each gill filament and arch were placed in $10 \mathrm{ml}$ of normal saline in petri-dish, later removed and then place on a slide on which 1-2 drops of saline solution were added and observed on a light microscope. While the mouth parts were washed out with normal saline into a petri dish and examined under a dissecting microscope for ectoparasites. Each sample was examined independently for parasites according to the protocol outlined in Obiekezie and Ekanem (1995). Identification of all the parasites recovered was carried out according to Paperna (1996), Roberts (2000) and Yamaguti (1961).

For endoparasites, the cavity of each fish was opened ventrally with a pair of scissors and the internal organs such as liver, ovaries, kidney, gall bladder, muscles, brain, and alimentary canal were removed and examined for endoparasites. The alimentary canal was divided into sections; oesophagus, stomach, duodenum, small intestine and large intestine. Any endoparasite recovered was introduced into normal saline to remove the mucus and other host debris. One to two drops of the preparation were placed on slide covered with slips and observed using a light microscope for endoparasites. Live nematodes were killed in extended form by pouring hot (steamed) $70 \%$ alcohol on them in petri dishes. Trematodes and Cestodes were fixed in Formalin-Acetic-Alcohol $15 \%$ formal-90\% alcohol-15\% glacial acetic acid) for two hours prior to staining. Acanthocephalans were shaken vigorously in cold and $4 \%$ formaldehyde until they had died. The number of parasite of each fish sample and their place of location in the fish were recorded. The parasites were stained in acetocarmines solution and mounted on permanent slides using Canada balsam.

Length-weight relationship: The relationship between Length (L) and Weight (W) of a fish was calculated by a mathematical curvilinear relation as Bagenal and Tesch (1978):

$$
\mathrm{W}=\mathrm{aL}^{\mathrm{b}}
$$

Where:

$$
\begin{aligned}
& W=\text { Weight of fish }(g)^{\prime} \\
& L=\text { Length of fish }(\mathrm{cm}) \\
& a=\text { Constant } \\
& b=\text { Growth Exponent }
\end{aligned}
$$

Logarithmic transformation of the equation gives a linear relationship as (Bagenal and Tesch, 1978):

$$
\log W=\log a+b \log L
$$

The values of $a$ and $b$ are then estimated through least squares regression analysis.

Condition factor: For calculating condition factor (K), The index to quantify the state of condition of a fish followed methods by Weatherley (1972). The K value was calculated in percentage as follows:

\section{$K=W 100 / L^{3}$}

Statistical analysis: The prevalence (\%), mean intensity and abundance were analyzed according to Bush et al. (1997). The relationships between factors such as host sex, weight, total length, locality, and parasitic infection were obtained from pooled data using analysis of variance (ANOVA). All statistical analysis was done using SPSS version 17.0.

\section{RESULTS}

Out of the 102 fishes examined for parasites, 32(31.4\%) fishes were infected with 134 parasites, belonging to one species of digenean (Clinostomium spp) (Plate 11), two species of Monogeneans (Gylodactylus spp and Dactylogyrus spp), Unidentified leeches were found (Plate12), four species of Cestodes (Wenyonia spp, Ligula spp, an unidentified spp and a Cysthcanthus), three species of Acanthocephala (Polymorphus spp (Plate 7), Neoechinorhyncus spp (Plate 9 and 10) and Echinorhynchus spp), ( five species of Nematodes (Camallanus spp (Plate 3 and 4), Procamallanus spp (Plate 2), Capillaria spp (Plate 1), Cucullanus spp and Philonema spp) and Lamproglena spp (Plate 8), Anchor of Lernaea spp (Plate 5 and 6) and unidentified copepods and Branchiura were the parasitic 
crustaceans found as shown in table 1 . The incidence of infestation by the parasites were recorded in increasing order $2.2 \%, 3.7 \%, 4.5 \%, 9.7 \%, 17.9 \%, 23.9 \%$ and $38.1 \%$ respectively. Among the body parts of the examined bagrid fishes, the intestine had the highest percentage load of 46 (34.3\%) parasites, while the fin had the least percentage load of $7(5.2 \%)$ parasites (table 2 ). The bagrid fishes belonged to four genera and seven species and has been subjected to both ecto and endo parasitological investigation. The species of Bagrid fishes examined include Bagrus bayad, Bagrus docmac, Auchenoglanis monkei, Auchenoglanis occidentalis, Auchenoglanis biscutatus, Chrysichthys auratus and Clarotes laticeps. All the fish species were infected, Auchenoglanis biscutatus (87.5\%) being the most preferred host while Auchenoglanis occidentalis $(12.5 \%)$ was the least. In all, 50 were females while only $21(42 \%)$ female fishes were infected with parasites, 42 were males while only $11(26.2 \%)$ male fishes were infected with parasites and 10 were juveniles with no parasitic infection. A higher prevalence, mean intensity and mean abundance in relation to sex was found in female than in male (table 3). From the composition of the parasites in their various body parts, it can be concluded that there was a high parasitic prevalence of endoparasites (54.5\%) than ectoparasites (45.5\%).

Prevalence of the Different Parasites Recovered in Bagrid Fishes.

Prevalence of the different parasites recovered in Bagrid fishes is shown in table 1. Nematodes recovered from bagrid fishes were Procamallanus spp., Camallanus spp., Capillaria spp., Cucullanus spp and Philonema spp embryo. Anchor of lernaea and Lamproglena were also recovered. Auchenoglanis occidentalis (38.5\%) had the highest prevalence of nematode, followed by Auchenoglanis biscutatus (32.4\%), Bagrus bayad (25\%) and Clarotes laticeps (25\%). In Bagrus docmac and Chrysichthys auratus the prevalence of nematode was $15.8 \%$ and $16.7 \%$ while the lowest nematode prevalence was found in Auchenoglanis monkei (7. 1\%).Cestodes recovered from bagrid fishes sampled include Wenyonia spp, Ligula spp, Cystacanthus and unidentified cestodes. The highest prevalence was found in Auchenoglanis occidentalis (23.1\%) while the lowest prevalence was found in Bagrus bayad (3\%). However, no cestode was recovered from Auchenoglanis monkei and Clarotes laticeps. Monogeneans recovered include Gyrodactylus spp. and
Dactylogyrus spp. The highest prevalence was found in Bagrus docmac (10.5\%) while the lowest prevalence was found in Bagrus bayad (9.4\%). There was no monogenean infection in Auchenoglanis occidentalis, Auchenoglanis biscutatus, Chrysichthys auratus, Auchenoglanis monkei and Clarotes laticeps. Clinostomium was the only digenean recovered from bagrid fishes sampled with highest prevalence in Auchenoglanis monkei (7.1\%) while the lowest prevalence was found in Auchenoglanis biscutatus (5.9\%). There was no digenean infection in Bagrus bayad, Bagrus docmac, Chrysichthys auratus, Auchenoglanis occidentalis and Clarotes laticep. Crustaceans recovered include Copepodes and Branchiura. The highest prevalence was found in Bagrus bayad (53.1\%) while the lowest prevalence is found in Auchenoglanis monkei (14. 3\%). Unidentifed leech was found in Bagrus bayad (3\%), Auchenoglanis monkei (7.1\%), Chrysichthys auratus (16.7\%), and Clarotes laticeps (25\%) with highest and lowest prevalence found in Clarotes laticeps and Bagrus bayad respectively. Acanthocephala recovered include Neoechinorhynchus spp., Polymorphus spp., and Echinorhynchus spp. The highest prevalence was found in Auchenoglanis monkei (64.3\%) while the lowest prevalence was found in Bagrus bayad (6.3\%). There was no record of acanthocephalan infection in Auchenoglanis occidentalis and Clarotes laticeps.

Prevalence of Parasites in Relation to their Distribution in Organs of Bagrid Fishes Sampled.

The prevalence of parasites in relation to their distribution in organs of bagrid fishes sampled is as shown in table 2 below, the intestine (34.3\%) was the major host for parasitic fauna of bagrid fishes in Anambra river basin, while the fin (5.2\%) was the least host for parasitic fauna. From the composition of the parasites in their various organs, it can be concluded that there was a high parasitic prevalence of endoparasites (54.5\%) than ectoparasites (45.5\%).

Prevalence, Mean Intensity, and Mean Abundance of Parasite in Relation to Sex.

The prevalence of parasite in relation to sex is shown in table 3. Male Bagrus bayad had parasite prevalence of $50 \%$ while in females the parasite prevalence was $25 \%$. There was no significant difference $(p>0.05)$ in the prevalence of parasite in male and female Bagrus bayad. In Bagrus docmac, the prevalence was $33.3 \%$ in female while in males the prevalence was $14.3 \%$, there 
was no parasitic infection in juveniles of this species. Comparing the prevalence of infection in Bagrus docmac showed that there was no significant difference ( $p>0.05$ ). In Auchenoglanis monkei, the parasite prevalence was $66.7 \%$ in female, while there was no parasite infection in male. Comparing the prevalence of infection in this species showed that there was no significant difference ( $p>0.05)$. In Auchenoglanis occidentalis, the parasite prevalence was $28.6 \%$ in female while there was no parasite infection in both male and juvenile. Comparing the prevalence of infection in Auchenoglanis occidentalis showed that there was no significant difference $(p>0.05)$. In Auchenoglanis biscutatus, the parasite prevalence was $100 \%$ in both male and female, while there was no parasite infection in juveniles of this species. Comparing the prevalence of infection in this species showed that there was significant difference $(p<0.05)$. In Chrysichthys auratus, the parasite prevalence was $75 \%$ in female and $33.3 \%$ in males while there was no parasitic infection in juveniles of this species. Comparing the prevalence of infection in Chrysichthys auratus showed that there was no significant difference ( $p>0.05)$. In Clarotes laticeps, the parasite prevalence was $50 \%$ in female, while there was no parasitic infection in male. Comparing the prevalence of infection in Clarotes laticeps showed that there was no significant difference $(p>0.05)$. A higher prevalence $(42 \%)$ in all the bagrid species sampled in relation to sex was found in the female while the male had the lesser prevalence (26.2\%). The juvenile had no parasitic infection. The female had higher mean intensity (4.76) than the male (3.09). The mean abundance was higher (2.00) in the female and lower (0.81) in male.

Length-Weight Relationship (LWR) of Bagrid Fishes Sampled and its K-Factor.

The length-weight relationship of Bagrid fishes sampled were shown in table 4, figs.1,2 and 3 below. The b values for the LWR of were under the range from 1.296 in $A$. occidentalis to 2.181 in $A$. biscutatus. The bagrid fishes had decreasing $b$-values in the following order Auchenoglanis biscutatus> Auchenoglanis monkei> Clarotes laticeps> Chrysichthys auratus > Bagrus bayad> Bagrus docmac> Auchenoglanis occidentalis. where Auchenoglanis occidentals and Auchenoglanis biscutatus were determined by coefficients $\left(R^{2}\right)>0.986$ and 0.974 respectively.
The mean $\mathrm{K}$ factor shows that Auchenoglanis occidentalis had the highest mean $\mathrm{K}$ factor $(1.61 \pm 0.74)$ while Bagrus bayad had the least $K$ factor $(0.75 \pm 0.02)$. A strong positive correlation existed between the length and weight of the bagrid fishes sampled. The values obtained for the length -weight relationship showed that Bagrus bayad was allometric in growth.

Comparing condition factor(K-factor) of Infected and Uninfected Fishes

The condition factor comparism of infected and uninfected bagrid fishes is as shown in table 5 . The condition factor of infected Bagrus bayad was slightly higher than that of uninfected Bagrus bayad, when the two groups were compared using t-test, showed that they were not significantly different $(p>0.05)$. However, that of other species have condition factor of uninfected slightly higher than that of the infected but when these two groups of each species are being compared using ttest, showed that Bagrus docmac, Auchenoglanis monkei, Chrysichthys auratus, Auchenoglanis occidentalis and Clarotes laticeps were not significantly different $(p>0.05)$ while that of Auchenoglanis biscutatus was highly significant $(p<0.05)$. This implies that the infected Bagrus bayad seems to be in a better state of wellbeing than the uninfected Bagrus bayad but this was not significant. The results of the condition factor (K) which was $>2$ indicated that some species was in good condition in Anambra River Basin, meaning that increase in length brought about the proportional increase in weight. However, that of other species have a low state of well-being in their infected than in their uninfected which is significant only in Auchenoglanis biscutatus of which the condition factor of infected falls under the category of poor condition fish ( $\mathrm{K}=1.00-1.19)$. Higher $\mathrm{K}$ - values in females than in males may be attributable to heavier weight of gonads in the females.

Relationship between K- factor and Parasitic Infections in Bagrid Species Sampled.

The relationship between the K-factor of bagrid species and prevalence of parasites is as shown in table 6 . The correlation between the $\mathrm{K}$ - factor of Bagus bayad $(r=0.10, p=0.59)$ and Bagrus docmac $(r=0.04, p=0.85)$ and parasite infection were poor and insignificant ( $p>0.05)$. The K-factor of Auchenoglanis monkei, Auchenoglanis biscutatus, Chrysichthys auratus and Clarotes laticeps, showed a moderate correlation with prevalence of parasitic infection. However, the correlation was not significant $(p>0.05)$. A significant 
$(p<0.05)$ and strong correlation was only observed between the K-factor of Auchenoglanis biscutatus $(r=0.96, p=0.001)$ and parasite infection

\section{DISCUSSION}

Different kinds of parasites were recovered from different locations in Bagrus bayad. It was observed that the seven bagrid fishes found in Anambra River were infected with a prevalence that ranges from $87.5 \%$ in Auchenoglanis biscutatus to $12.5 \%$ in Auchenoglanis occidentalis. It could be inferred from this that Auchenoglanis biscutatus had the least resistance to parasitic infection while Auchenoglanis occidentalis had the highest resistance to parasitic infection. This could be said to be as a result of Auchenoglanis biscutatus wide range of feeding as an omnivore at all stage of its development. This is in line with the findings of Omeji et al. (2011). The recovered parasite includes both ecto and endo parasites. The parasitic crustaceans were the most abundant parasite in the fish sampled which could be said to be because of its role as an intermediate host in the transfer and development of most fish parasite. This agrees with the findings of Akinsaya et al. (2007). Neoechinorhynchus, Procamallanus and Camallanus were the main helminth parasites found in almost all the bagrid fishes sampled which was in contrast with Akinsaya et al. (2007). Chrysichthys nigrodigitatus was mainly infected with Proteocephalis sp., Aspidogastrea africanus and Paracamallanus cyathopharynx.

The major parasitic fauna was found in the intestine followed by the gills and then the stomach, while the least fauna for parasitic infection was the fin. The higher number of parasites found in the intestine could be associated with the fact that most digestive activities takes place in the intestine resulting in the release of parasite ova/cysts in food particles. This agreed with findings of Ezenwaji et al. (2005); Onyedineke et al. (2010). The female fishes had more parasitic infection than the male, while juvenile was found to be uninfected by the parasite. Out of 32 infected bagrid fishes in Anambra River, female had a prevalence of $21(42 \%)$ while male had a prevalence of 11 (26.2\%). This report is like that reported by lbiwoye et al. (1996) at freshwater Fadama of Bida area in which there was a higher prevalence $(42.7 \%)$ of parasite in the female Clarias spp than in the males (26.5\%). The high prevalence recorded in the females could be because of ecological factors emanating from the feeding differences between the male and female species. Out of the 134 parasites recovered from the seven species of bagrid fishes only about 80 parasites are worms, the high worm burden could be because of their feeding habit (they are mainly omnivores). The overall incidence of parasite was low (31.4\%) when compared with high percentage (85.2\%) recorded in wild populations of Synodontis spp. caught in Zaria dam (Auta et al., 1999 and Ezenwaji, 2004; Ezenwaji et al. 2005) from Anambra River basin, this may be due to ecological differences between habitats at the time of sampling. Williams and Jones (1994) opined that parasitism varies from one ecosystem to the other and this is influenced by the interplay of mixed biotic and abiotic factors. The overall incidence of parasite can also be said to be like the recorded prevalence of $33.5 \%$ by Ibiwoye et al. (1996) in freshwater Fadama of Bida area which could be said to have similar ecological habitat with Anambra River basin.

The ectoparasite encountered in the seven species of bagrid fishes in Anambra River have been implicated as causative agents of various fish diseases which reduces production, economic losses, and increased susceptibility to predation. B. bayad which have high incidence of parasitic crustaceans and monogeneans was noticed to have odd appearance due to the infection of this ectoparasite on their external body such as the skin, fin, and gills. The endoparasite encountered in seven species of bagrid fishes have been implicated as causative agent of various debilities in several fish species in tropical freshwater. This is in line with the findings of Owolabi (2008). Injuries associated with points of attachment of these endoparasites among many fishes also serve as entry point for secondary infection with opportunistic bacteria and fungi and thereby compromising the health status of their host. The management of this ecto and endoparasite are very important because their presence may result in skin undulation and various skin diseases and thus consumers may reject the fish or they might as well infect other fishes or animals when they are consumed.

Length and weight growth are regulated by different endocrine systems and may not necessarily happen at the same time. These growth processes can affect the fitness of the fish in many ways and have different energetic costs. 
Auchenoglanis occidentalis had the highest mean $\mathrm{K}$ factor $(1.61 \pm 0.74)$ thus indicates that the environment of the river is more suitable for this species, while Bagrus bayad had the least $\mathrm{K}$ factor $(0.75 \pm 0.02)$. The $\mathrm{K}$ decreases because the fish are growing rapidly in length relative to weight, changing their body shape to a longer, leaner shape. Ultimately, this is advantageous for their transition to the marine environment where they must swim for long distances in open water. Fish affected by parasites, bacteria, virus, or bad water factors stop eating and this was reflected in reduced $\mathrm{k}$ index. This is in line with the report of Shinkafi and Ipinjolu (2010). The finding also shows that the $b$ values of Auchenoglanis occidentalis sp. are lower than $3(b<3)$ show a signs of negative allometric growths. When $b$ is equal to 3 , this indicates that the fish grows isometrically (Amin et al., 2008; Rahim et al., 2009). This also agrees with the report of Ezenwaji et al., (2005).

Table 1: Prevalence of the Different Parasites Recovered in Bagrid Fishes.

\begin{tabular}{|c|c|c|c|c|c|c|c|}
\hline $\begin{array}{r}\text { Parasites } \\
\text { Species (\%) }\end{array}$ & $\begin{array}{l}\text { Nematodes } \\
\text { (\%) }\end{array}$ & $\begin{array}{l}\text { Cestodes } \\
(\%)\end{array}$ & $\begin{array}{l}\text { Monogeneans } \\
\text { (\%) }\end{array}$ & Digeneans (\%) & $\begin{array}{l}\text { Crustaceans } \\
\text { (\%) }\end{array}$ & $\begin{array}{l}\text { Leeches } \\
(\%)\end{array}$ & Acanthocephal (\%) \\
\hline $\begin{array}{l}\text { B. bayad } \\
(34 \%)\end{array}$ & $\begin{array}{l}\text { Procamallanus } \\
\text { spp. } \\
\text { Camallanus spp. } \\
\text { Capillaria spp. } \\
(25 \%)\end{array}$ & $\begin{array}{l}\text { Wenyonia spp. } \\
(3 \%)\end{array}$ & $\begin{array}{l}\text { Gyrodactylus } \\
\text { spp. } \\
(9.4 \%)\end{array}$ & - & $\begin{array}{l}\text { Copepodes } \\
\text { Branchiura } \\
(53.1 \%)\end{array}$ & $\begin{array}{l}\text { Unidentifie } \\
\text { d leech } \\
(3 \%)\end{array}$ & $\begin{array}{l}\text { Polymorphus } \\
\text { spp } \\
(6.3 \%)\end{array}$ \\
\hline $\begin{array}{l}\text { B. docmac } \\
(18 \%)\end{array}$ & $\begin{array}{l}\text { Procamallanus } \\
\text { spp. } \\
(15.8 \%)\end{array}$ & $\begin{array}{l}\text { Wenyonia spp. } \\
(10.5 \%)\end{array}$ & $\begin{array}{l}\text { Dactylogyrus } \\
\text { spp. }(10.5 \%)\end{array}$ & _ & $\begin{array}{l}\text { Copepodes } \\
\text { Branchiura } \\
(47.4 \%)\end{array}$ & - & $\begin{array}{l}\text { Neoechinorhynchus } \\
\text { spp. } \\
(15.8 \%)\end{array}$ \\
\hline $\begin{array}{l}\text { A. monkey } \\
(40 \%)\end{array}$ & $\begin{array}{l}\text { Cucullanus spp. } \\
(7.1 \%)\end{array}$ & _ & - & $\begin{array}{l}\text { Clinostomiumsp } \\
p \\
(7.1 \%)\end{array}$ & $\begin{array}{l}\text { Copepodes } \\
(14.3 \%)\end{array}$ & $\begin{array}{l}\text { Unidentifie } \\
\text { d leech } \\
(7.1 \%)\end{array}$ & $\begin{array}{l}\text { Neoechinorhynchus } \\
\text { spp. } \\
(64.3 \%)\end{array}$ \\
\hline $\begin{array}{l}\text { A.occidentalis } \\
(12.5 \%)\end{array}$ & $\begin{array}{l}\text { Cucullanus spp. } \\
(38.5 \%)\end{array}$ & $\begin{array}{l}\text { Ligula spp. } \\
(23.1 \%)\end{array}$ & _ & _ & $\begin{array}{l}\text { Copepodes } \\
(38.5 \%)\end{array}$ & _ & _ \\
\hline $\begin{array}{l}\text { A. biscutatus } \\
(87.5 \%)\end{array}$ & $\begin{array}{l}\text { Capillaria } \\
\text { spp } \\
\text { Procamallanus } \\
\text { spp } \\
\text { Camallanus } \\
\text { spp } \\
\text { Philonema } \\
\text { spp.(embryo) } \\
(32.4 \%)\end{array}$ & $\begin{array}{l}\text { Ligula spp } \\
\text { Unidentified } \\
\text { cestodes } \\
(18.8 \%)\end{array}$ & _ & $\begin{array}{l}\text { Clinostomium } \\
\text { spp. }(5.9 \%)\end{array}$ & $\begin{array}{l}\text { Copepodes } \\
(29.4 \%)\end{array}$ & _ & $\begin{array}{l}\text { Echinorhynchus spp. } \\
\text { Neoechinorhynchus } \\
\text { spp. } \\
(14.7 \%)\end{array}$ \\
\hline $\begin{array}{l}\text { C. auratus } \\
(50 \%)\end{array}$ & $\begin{array}{l}\text { Capillaria spp. } \\
(16.7 \%)\end{array}$ & $\begin{array}{l}\text { Cystacanthus } \\
(5.6 \%)\end{array}$ & _ & - & $\begin{array}{l}\text { Copepods } \\
\text { Branchiura } \\
(33.3 \%)\end{array}$ & $\begin{array}{l}\text { Unidentifie } \\
\text { d leech } \\
(16.7 \%)\end{array}$ & $\begin{array}{l}\text { Neoechinorhynchus } \\
\text { spp. } \\
(27.8 \%)\end{array}$ \\
\hline $\begin{array}{l}\text { C. laticeps } \\
(20 \%)\end{array}$ & $\begin{array}{l}\text { Procamallanus } \\
\text { spp } \\
(25 \%)\end{array}$ & - & - & - & $\begin{array}{l}\text { Copepods } \\
(50 \%)\end{array}$ & $\begin{array}{l}\text { Unidentifie } \\
d \quad \text { leech } \\
(25 \%)\end{array}$ & _- \\
\hline
\end{tabular}


Table 2: Prevalence of Parasites in Relation to their Distribution in Various Body Parts of Bagrids Fishes.

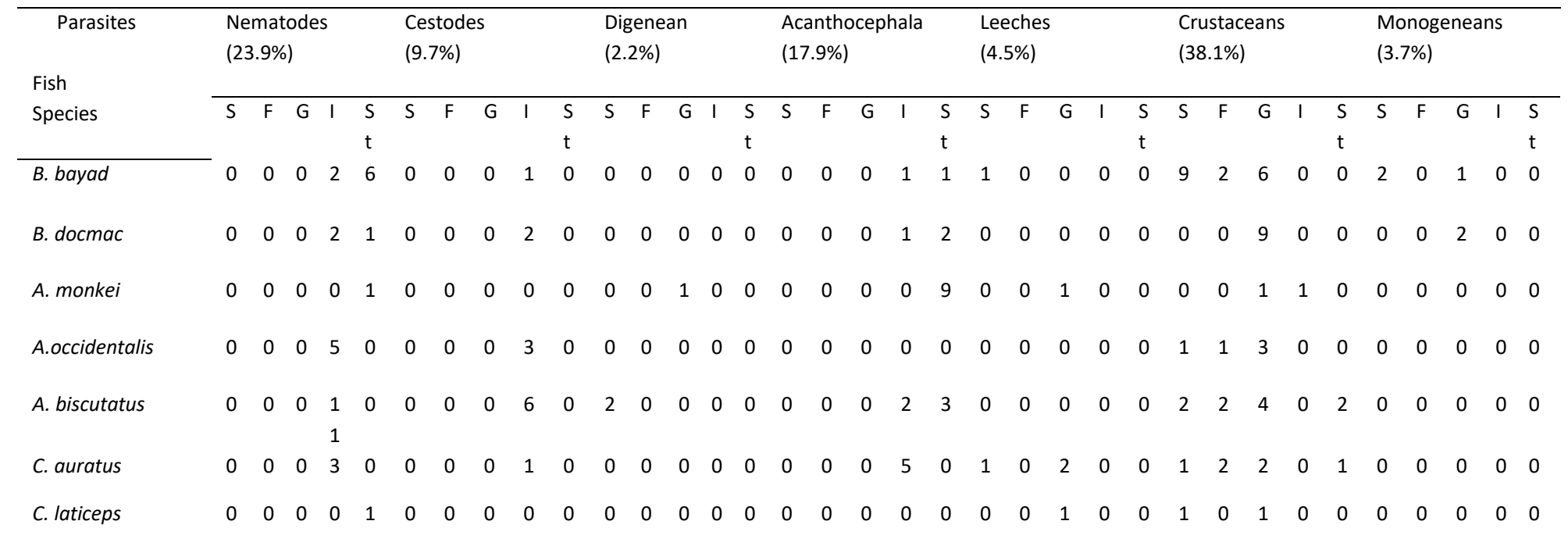

S=skin $\mathrm{F}=$ fin $\mathrm{G}=$ gills $\mathrm{I}=$ intestine $\mathrm{St}=$ stomach

Table 3: Prevalence, Mean Intensity, and Overall Mean Abundance of the Species of Bagrid Fishes in Relation to their Sex.

\begin{tabular}{|c|c|c|c|c|c|c|c|c|}
\hline $\begin{array}{l}\text { Fish } \\
\text { Species/Sample } \\
\text { Size }\end{array}$ & $\begin{array}{l}\text { Fish } \\
\text { Sex }\end{array}$ & $\begin{array}{l}\text { No of fish } \\
\text { examined }\end{array}$ & $\begin{array}{l}\text { No of fish } \\
\text { infected }\end{array}$ & $\begin{array}{l}\text { Mean } \\
\text { standard } \\
\text { length }\end{array}$ & $\begin{array}{l}\text { Mean } \\
\text { standard } \\
\text { weight }\end{array}$ & $\begin{array}{l}\text { Percentage } \\
\text { prevalence }\end{array}$ & $\begin{array}{l}\text { Mean } \\
\text { intensity }\end{array}$ & $\begin{array}{l}\text { Overall } \\
\text { mean } \\
\text { abundance }\end{array}$ \\
\hline \multirow[t]{2}{*}{ Bagrus bayad / 32} & Male & 12 & 6 & 27.84 & 151.60 & 50 & 2.00 & \multirow{2}{*}{1.00} \\
\hline & Female & 20 & 5 & 27.65 & 141.70 & 25 & 4.00 & \\
\hline \multirow{3}{*}{$\begin{array}{l}\text { Bagrus } \\
\text { docmac/28 }\end{array}$} & Male & 14 & 2 & 17.17 & 48.30 & 14.28 & 7.00 & \multirow{3}{*}{0.68} \\
\hline & Female & 9 & 3 & 16.84 & 49.34 & 33.33 & 3.00 & \\
\hline & Juvenile & 5 & 0 & 8.44 & 16.32 & -------- & ------- & \\
\hline Auchenoglanis & Male & 2 & 0 & 16.30 & 45.30 & 0 & ------ & \multirow{2}{*}{2.80} \\
\hline monkei/5 & Female & 3 & 2 & 18.06 & 60.90 & 66.70 & 1.50 & \\
\hline Auchenoglanis & Male & 6 & 0 & 11.72 & 17.15 & ------- & ------- & \multirow{3}{*}{0.81} \\
\hline \multirow[t]{2}{*}{ occidentalis/16 } & Female & 7 & 2 & 13.35 & 24.04 & 28.6 & 3.50 & \\
\hline & Juvenile & 3 & 0 & 7.70 & 11.23 & ------- & ------- & \\
\hline Auchenoglanis & Male & 2 & 2 & 18.05 & 60.25 & 100 & 1.00 & \multirow{3}{*}{4.25} \\
\hline \multirow[t]{2}{*}{ biscutatus/8 } & Female & 5 & 5 & 16.90 & 49.88 & 100 & 1.00 & \\
\hline & Juvenile & 1 & 0 & 12.60 & 29.00 & ----- & ------ & \\
\hline Clarotes & Male & 3 & 1 & 14.67 & 32.60 & 33.3 & 3.00 & \multirow{3}{*}{2.25} \\
\hline \multirow[t]{2}{*}{ auratus/8 } & Female & 4 & 3 & 13.78 & 30.93 & 75 & 1.33 & \\
\hline & Juvenile & 1 & 0 & 6.90 & 9.70 & ------ & ------- & \\
\hline \multirow[t]{2}{*}{ Claroteslaticeps/5 } & Male & 3 & 0 & 13.07 & 33.80 & ----- & ----- & \multirow{2}{*}{0.80} \\
\hline & Female & 2 & 1 & 18.75 & 50.55 & 50 & 2.00 & \\
\hline
\end{tabular}


TABLE 4: Length-weight relationship (LWR) of Bagrid Fishes and its Condition factor (K).

\begin{tabular}{|c|c|c|c|c|c|c|c|c|c|}
\hline Species & $a$ & b & $r$ & $\begin{array}{l}\text { Min } \\
\text { length }\end{array}$ & Max length & Min weight & Max weight & K- factor & Figure \\
\hline B. bayad & -0.334 & 1.741 & 0.982 & 20.70 & 32.50 & 95.00 & 220.00 & $0.75 \pm 0.02$ & Fig.1 \\
\hline B. docmac & 0.006 & 1.348 & 0.962 & 7.20 & 21.20 & 14.00 & 53.00 & $1.34 \pm 0.15$ & Fig. 2 \\
\hline A. monkei & -0.677 & 1.955 & 0.999 & 7.50 & 19.50 & 10.90 & 72.80 & $1.35 \pm 0.31$ & $*$ \\
\hline A. occidentalis & -0.091 & 1.296 & 0.986 & 7.20 & 17.70 & 10.50 & 40.00 & $1.61 \pm 0.74$ & Fig. 3 \\
\hline A. biscutatus & -0.976 & 2.181 & 0.974 & 12.6 & 19.60 & 29.00 & 75.50 & $1.07 \pm 0.16$ & $*$ \\
\hline C. auratus & -0.605 & 1.815 & 0.980 & 6.90 & 17.10 & 9.70 & 49.00 & $1.34 \pm 0.71$ & $*$ \\
\hline Clarotes laticeps & -0.673 & 1.875 & 0.997 & 10.20 & 19.00 & 16.00 & 52.10 & $1.04 \pm 0.14$ & $*$ \\
\hline
\end{tabular}

* where $\mathrm{a}$ and $\mathrm{b}$ means regression coefficients and $\mathrm{r}$ means correlation coefficient.and k-factor means condition factor

Figure 1: Length-weight relationship of Bagrus bayad in Anambra river basin

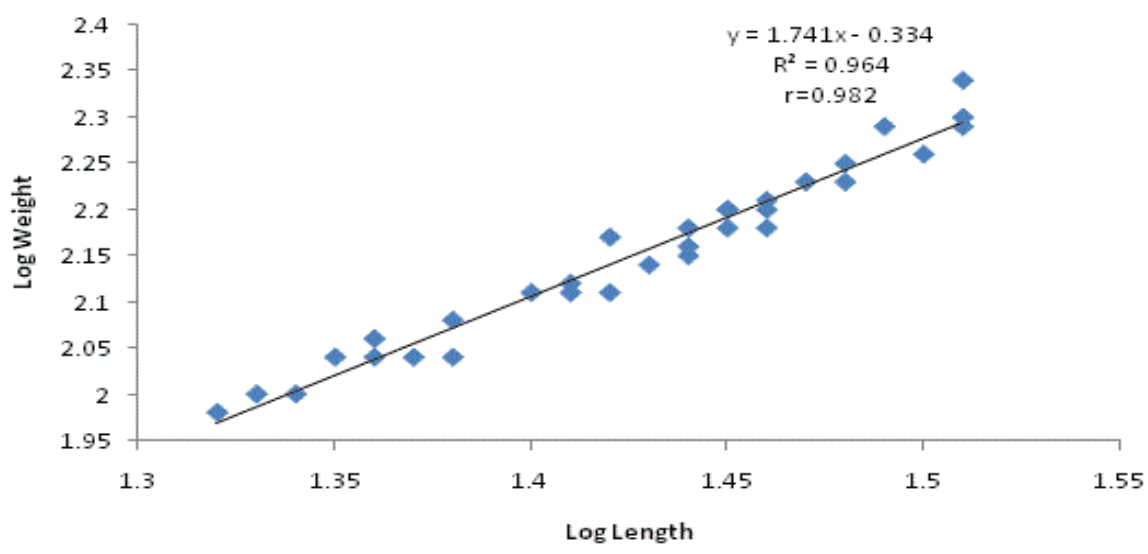

Figure 2: Length-weight relationship of Bagrus docmac in Anambra river basin

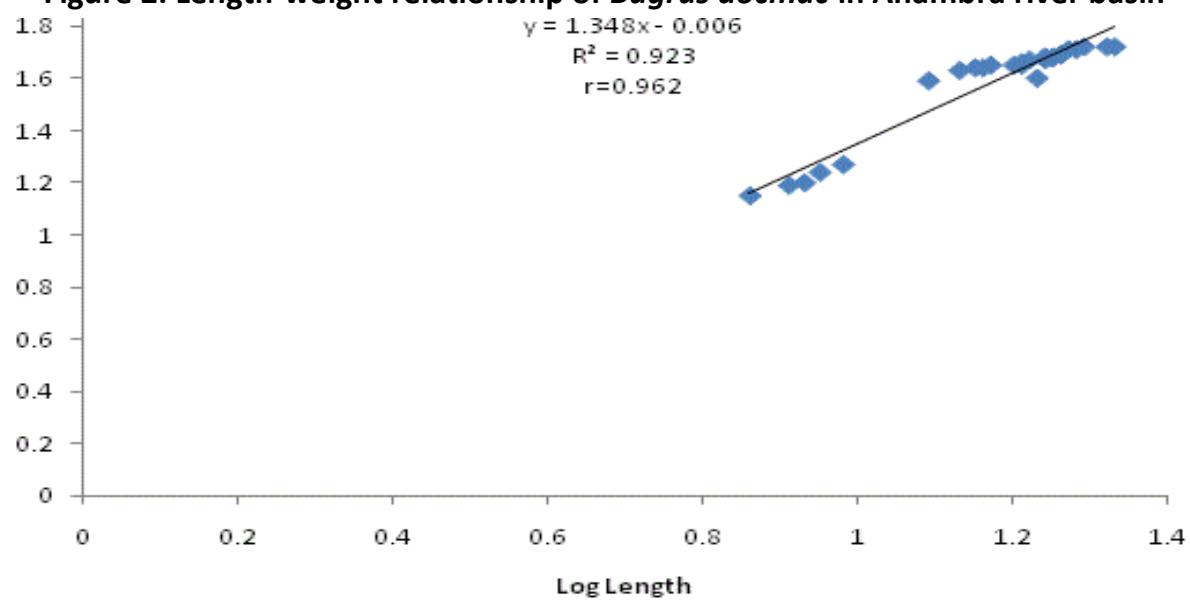


Figure 3: Length-weight relationship of Auchenoglanis occidentalis in Anambra river basin

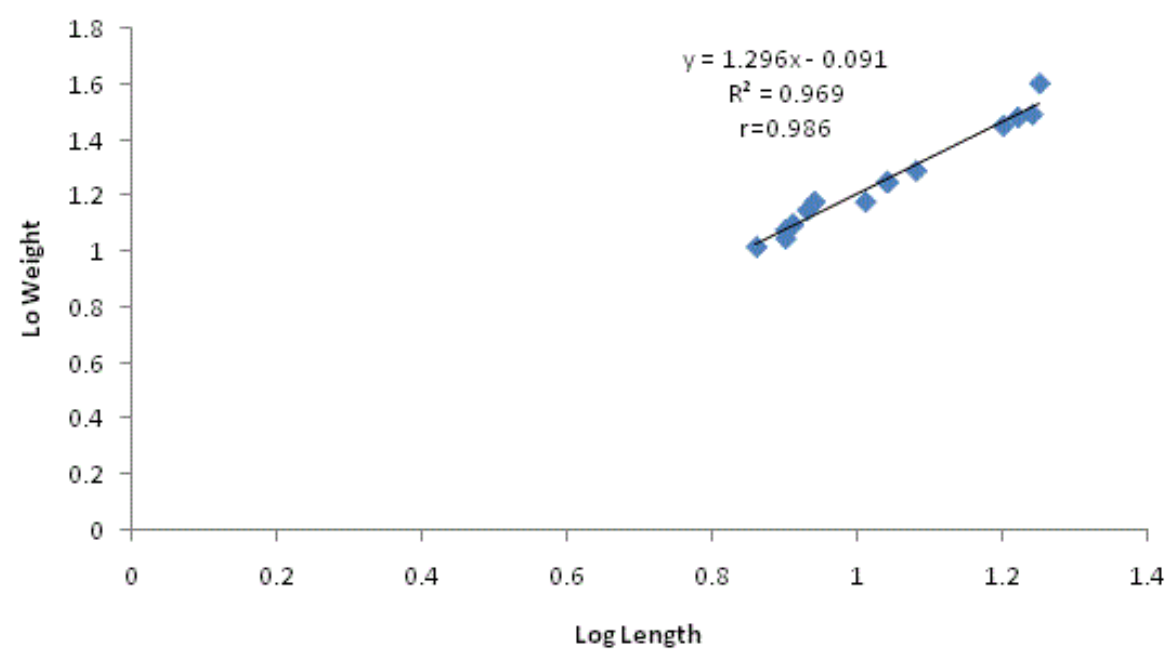

Table 5: Comparing K-factor of Infected and Uninfected Fishes.

\begin{tabular}{|l|l|l|l|l|}
\hline Bagrid species & Infected & Uninfected & P-value & Remarks \\
\hline B.bayad & $0.77 \pm 0.04$ & $0.74 \pm 0.03$ & 0.58 & NS \\
\hline B.docmac & $1.27 \pm 0.35$ & $1.35 \pm 0.17$ & 0.84 & NS \\
\hline A.monkei & $1.01 \pm 0.03$ & $1.58 \pm 0.50$ & 0.38 & NS \\
\hline A.occidentalis & $0.71 \pm 0.01$ & $1.74 \pm 0.19$ & 0.06 & NS \\
\hline A.biscutatus & $1.02 \pm 0.02$ & $1.45 \pm 0.00$ & 0.00 & S \\
\hline C.auratus & $0.97 \pm 0.01$ & $1.71 \pm 0.45$ & 0.14 & NS \\
\hline C.laticeps & $0.76 \pm 0.00$ & $1.12 \pm 0.15$ & 0.37 & NS \\
\hline
\end{tabular}

NS= Not significant, $\mathrm{S}=$ Significant

Table 6: Relationship between Parasitic Infections in Bagrid Species.

\begin{tabular}{|l|l|l|l|l|}
\hline Bagrid species & $\mathbf{R}$ & $\mathbf{r}^{\mathbf{2}}$ & $\mathbf{P}$-value & Remarks \\
\hline B.bayad & 0.10 & -0.02 & 0.59 & NS \\
\hline B.docmac & 0.04 & -0.04 & 0.85 & NS \\
\hline A.monkei & 0.45 & -0.06 & 0.45 & NS \\
\hline A.occidentalis & 0.48 & 0.17 & 0.06 & NS \\
\hline A.biscutatus & 0.96 & 0.90 & 0.001 & S \\
\hline C.auratus & 0.56 & 0.20 & 0.15 & NS \\
\hline C.laticeps & 0.52 & 0.03 & 0.37 & NS \\
\hline
\end{tabular}

$\mathrm{R}=$ coefficient while $\mathrm{r}=$ correlation $\mathrm{NS}=$ Not significant, $\mathrm{S}=$ Significant 


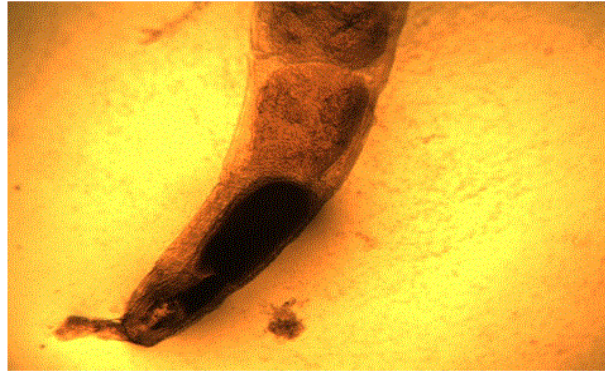

Plate 1: Capillaria spp. anterior region

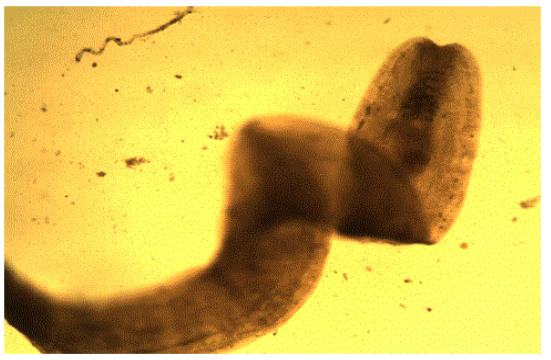

Plate 3: Camallanus spp. posterior region

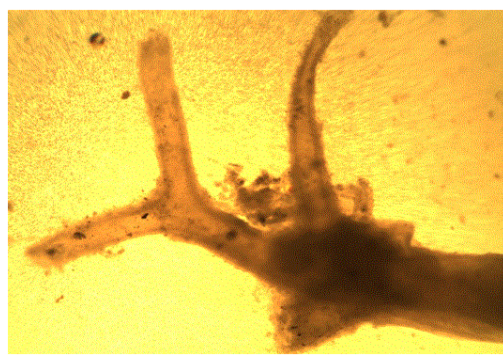

Plate 5:Anchor of Lernaea spp.

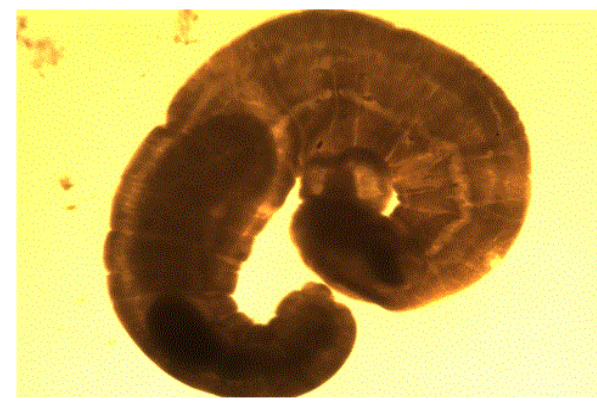

Plate 7: Polymorphus spp

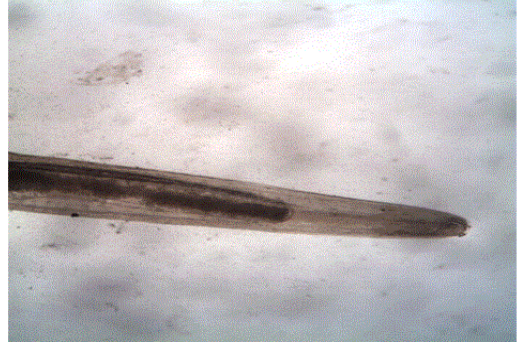

Plate 2:Procamallanus spp. anterior region

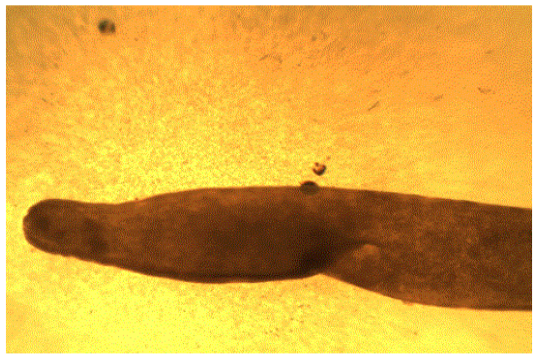

Plate 4: Camallanus spp.anterior region

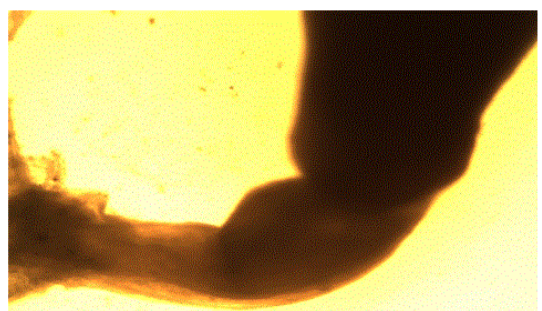

Plate 6: Anchor of Lernaea spp.

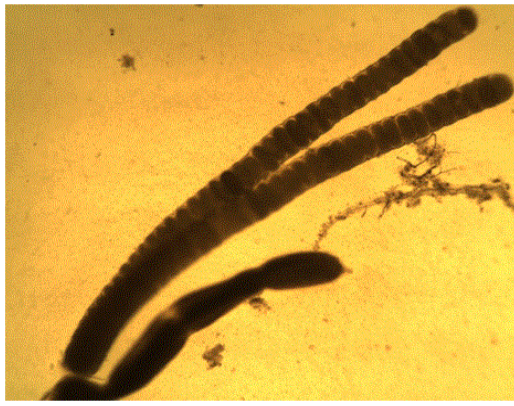

Plate 8: Lamproglena spp (Posterior region) 


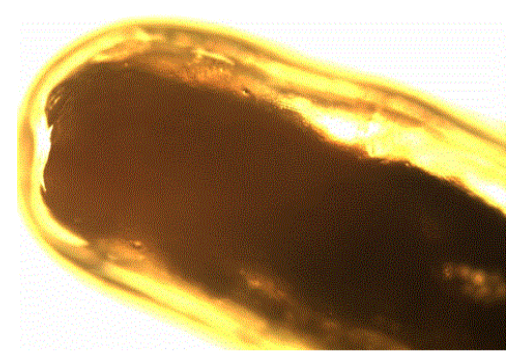

Plate 9: Neochinorhynchus spp. posterior region

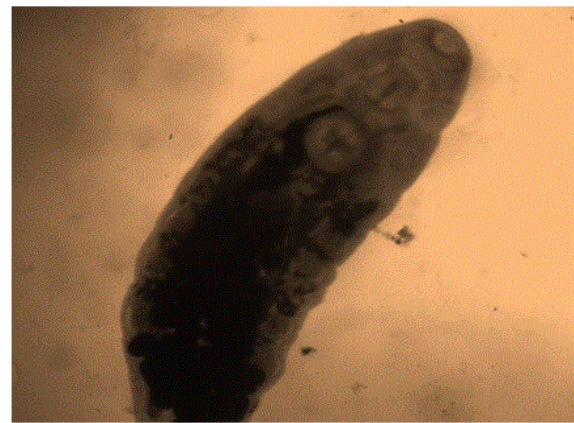

Plate 11: Clinostomium spp

\section{CONCLUSION}

Parasitological examination and condition factor of bagrid species was carried out in 102 fishes, 32(31.4\%) were infected with 134 parasites, belonging to one species of digenean (Clinostomium spp), two species of Monogeneans (Gylodactylus spp and Dactylogyrus spp), Unidentified leeches were found, four species of Cestodes (Wenyonia spp, Ligula spp, an unidentified spp and a (ysthcanthus), three species of Acanthocephala (Polymorphus spp, Neoechinorhyncus spp and Echinorhynchus spp), five species of Nematodes (Camallanus spp, Procamallanus spp, Capillaria spp,Cucullanus spp and Philonema spp) and unidentified copepods The major parasitic fauna was found in the intestine followed by the gills and then the stomach, while the least fauna for parasitic infection was the fin. The findings of this study on A. occidentalis in Anambra River Basin revealed that increase in standard length would lead to increase in weight variables in the length-weight relationships, growth pattern of this species is allometric and that the species is also in good condition in the river. The highest prevalence was found in Auchenoglanis monkei (64.3\%) while the lowest prevalence was found in Bagrus bayad (6.3\%). The findings of this study on Bagrus fishes

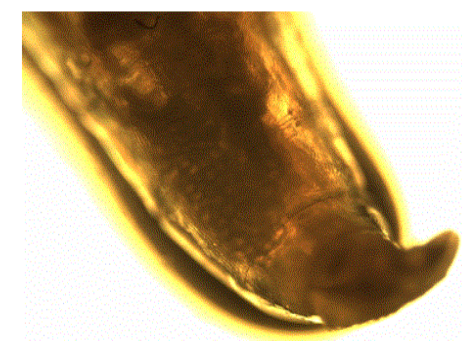

Plate 10: Neochinorhynchus spp. Anterior region

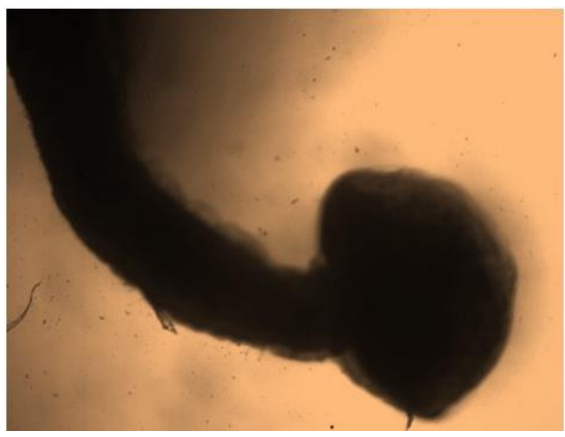

Plate12: Anterior region of an unidentified leech.

revealed that the condition factor ranged from 0 $.75 \pm 0.02-1.61 \pm 0.74$. The $b$ values for the LWR of were under the range from 1.296 in A. occidentalis to 2.181 in $A$. biscutatus. The finding also shows that the $b$ values of Auchenoglanis occidentalis sp. are lower than $3(b<3)$ show a signs of negative allometric growths. When $b$ is equal to 3 , this indicates that the fish grows isometrically.

\section{ACKNOWDGEMENTS}

We thank the staff of zoology garden for providing the needed facilities and for their assistance in the course of this work.

\section{CONFLICT OF INTEREST}

None of the authors having any conflict of interest.

\section{REFERENCES}

Akinsanya B., Otubanjo O. A., Ibidapo C. A., Helminth Bioload of Chrysichthys nigrodigitatus (Lacepede 1802) from Lekki Lagoon Lagos, Nigeria. Turkish Journal of Fisheries and Aquatic Sciences. 2007, 7: 83-87. 
Anyanwu P. E., Influence of salinity on survival of fingerlings of the estuarine catfish Chrysichthys nigrodigitatus (Lacepede). Journal on Fish Biology and Aquaculture. 1991, 99 (1/2): $157-165$.

Auta J., Oniye S. J., Adakole T., The helminthes parasites of the gastrointestinal tracts of Synodontis species in Zaria, Nigeria.Journal of Pure and Applied Science. 1999, 2: 47-53.

Bagenal T.B., Te sch A.T., Conditions and Growth Patterns in Fresh Water Habitats. Blac kw ell Scientific Publications, Oxford

Baron V. D., Orlov, A. A., Golubtsov, A. S., African catfishes.A new group of weakly electric fish. Izvestiya Rossiikoi Akademii NaukSeriya Biologicheskaya. 1996, (1): 106-111.

Beyer J.E., On length-weight relationship computing the mean weight of the fish of a given length class. Fishbyte. 1987, 5(1): 11-13.

Bush A. O., Lafferty K. D., Lotz, J. M., Shostak A. W., Parasitology meets ecology on its own terms. Journal of Parasitology. 1997, 83: 575-583.

Ekanem S.B., Some reproductive aspect of Chrysichthys nigrodigitatus (Lacepede) from cross river Nigeria. Naga ICLARM quarterly. 2002, 2 (2): 413-1157.

Ekanem A. P., Eyo V. O., Sampson A. F., Parasites of landed fish from Great Kwa River, Calabar, Cross River State, Nigeria. International Journal of Fisheries and Aquaculture. 2011, (12): 225-230.

Ezenwaji H.M.G., A study of the reproductive aspects of Chrysichthys nigrodigitatus (Lacepede) using dorsal spine.J. Fish Biol. 2004, 19 (3): 345-351.

Ezenwaji H. M. G., Aspect of the Biology of Clarias gariepinus in Anambra River Basin.Maturation and Condition Factor. Journal of Agricultural Science and Technology. 1998, 2(1): 52-55.

Ezenwaji N.E., Agigwo J.N., Ilozumba P.C.O., Ezenwaji H.M.G., Helminth Endo-parasites Of Mochokids in the Tropical Rainforest River System. Animal Research International. 2005, 2 (2): 346-352.

Fomena A., and Bouix G., Myxosporea (Protozoa: Myxozoa) of freshwater Fishes in Africa: keys to genera and species. Systematic Parasitology. 1997, 37:161-178.

Gayanilo, F.C., D. Pauly., FAO ICL ARM stock assessment tools (FISA T): References $M$ anual, FAO Computerized Information Series (Fisheries). 1997, (8). pp: 262.
Hoffman G. L., Parasites of North American freshwater fishes.Second edition. Comstock Publishing Associates, Ithaca, New York. 1999.

Ibiwoye T. I. I., Sule A. M., Okojie P. U. A., Agbuntale J. J.,Prevalence of helminth infestation. In fresh water fadama fishes of Bida Area, Nigeria. National Institute for Freshwater Fisheries Research (NIFFR) Annual Report, ISSN 0331-9296. 1996, 43-49pp.

Idodo-Umeh G., Freshwater fishes of Nigeria. Taxonomy, Ecological notes, Diet, and Utilization. Idodo-Umeh publishers Limited, Benin City. 2003, 232pp.

Khalil L. F., Polling, K., Checklist of the African Freshwater Fishes. University of the North Department of Zoology. Republic of South Africa. 1997, p. 189.

LeCren E D., The length-weight relationship and seasonal cycle in gonad weight an d condition in the Perch (Perca fluviatilis). Journal Animal Ecol. 1951,20:201-19.

Obiekezie A. I. Ekanem, D., Experimental infection of Heterobranchus longifilis (Teleosti: Clariidae) with Trichodina maritinkae (Ciliophora: Peritrichida). Aquatic Living Resources. 1995, 8: 439-443.

Obiekezie A. I., Enyenihi U. K., Henneguya Chrysichthy Sp. Nov (Protoza: myxozoa) from the gills of the estuarine catfish, Chrysicthys nigrodigitatus (Lacepede) in the Cross River. Estuary Nigeria Journal. 1988, 401-403.

Omeji S., Solomon, S.G., Idosa E.S., A comparative Study of the Common Protozoan Parasites of Clarias gariepinus from the Wild and Cultured Environments in Benue State, Nigeria. Journal of Parasitology Research. 2011, 199.

Onyedineke N. E., Obi, U., Ofoegbu P. U., Ukogo, I., Helminth Parasites of Some Freshwater Fish from River Niger at Illushi, Edo State, Nigeria. Journal of American Science. 2010, 6(3):16-21

Owolabi O. D., Endoparasitic helminthes of the upsidedown catfish Synodontis membrenaceus in Jebbalake, Nigeria. International Journal of Zoological Research. 2008, 4(3):181-188.

Paperna I., Parasites, infections, and diseases of fish in Africa. An update, Food, and Agricultural Organization. CIFA Technical Paper. 1996, 9: 166180. 
Reynold T.D., The Biology of Clupeids in the New Volta Lake. In: Man-Made Lakes, Obengi, L.E. (Ed.). Ghana University Press, Ghana. 1968.

Roberts R. J., Fish Pathology.3rd edition. Hagerman, Idaho, p. 472. Williams, H. and Jones, A. (1994). Parasitic worms of fish. Taylor and Francis London. 2000. Journal of Helminthology, 68(4): 361-363.

Shinkafi B.A., and Ipinjolu J.K., Morphometric Relationships and Relative Condition Factor of Auchenoglanis occidentalis (Cuvier and
Valenciennes) from River Rima, North-Western Nigeria. Journal of Fisheries International. 2010, 5(4).: 61-66

Weatherley A.H., Growth, and Ecology of Fish Populations. Academic Press, California, USA., ISBN: 0127390502, 9780127390505, 1972, Pages: 293.

Yamaguti S., Nematodes of Vertebrates Systema Helminthum, New York, Interscience publishers Incorporation. 1961, 2-61.
*Corresponding Author:

\section{N. E. Ezenwaji *}

Email: ngozi.ezenwaji@unn.edu.ng 